\title{
OPTIMUM USE DISMENTAL CONCRETE AS A RECYCLED AGGRAGATE IN CONCRETE
}

\author{
Arvind Vishwakarma \\ Assistant Professor, Department of Civil Engineering \\ Oriental University, Indore, Madhya Pradesh, India
}

\begin{abstract}
Environmental protection and conservation of natural resources is the essence of any development. Also, current $R \& D$ is constantly engaged in technological and industrial development in the field of upcoming Construction projects. To eliminate the environmental impact associated with the production of cement, it is extremely important to offer alternative binders for concrete. Consequently, extensive diving continues when replacing cement with various wastes and is acceptable. Since partial replacement of cement and/or aggregate has already been undertaken in the concrete industry, attempts have been made to fly ash, crushed concrete, waste glass, rice husk, etc. If fewer wastes are considered convenient and economical for concrete production, significant gains will be made in waste management and lower construction costs. In the course of the work, the main impact to use glass powder(GP) as a partial substitute for cement with various percentages is checked. In this project, the optimal ratio of recycled concrete aggregate (RA is added with partially replaced natural aggregate (NA). For testing, recycled aggregates is converted into the crushed concrete grade M25. The combination of natural aggregate(NA) and recycled aggregate(RA). The combination mix preparations of $75 \%$ NA and $0-25 \%$ RA in a ratio that It is consistent with adequate results, additionally tested for compressive and bending strength, after 7, 14, 28 days and are compared with ordinary M25 concrete.
\end{abstract}

Keywords; Natural aggregates (NA), Recycled aggregates (RA), M25, cement, Environmental protection

\section{INTRODUCTION}

The development of our country is increasing day by day. Concrete is one of the materials that make up the bulk of the construction industries. The use of any recycled material helps maintain a green environment by avoiding construction waste. Recycled aggregates (RA) are obtained demolition of structural concrete into small pieces components of different structures like old buildings, concrete waste of rigis and flexible pavements or roads, bridges and other structures, etc. The construction project is necessity for development of any country. This is the best and grounded construction industry. Recycling in the field of environmental protection and the environment. Recycling of dismantle concrete as it converted into the recycled aggregate(RA). The Industry also focused on the demolition structure of composers in the ensemble of decoration structures to resolve the problems of transformations and destruction of waste materials

At the of its salvage value of building structure, the structures deteriorated beyond the possibility of repairs, structures transformed into debris resulting from natural disasters activity like floods-earthquakes- tsunamis, \&manmade disasters/war, etc.), structures not meeting needs in the current scenario, old structures to be demolished to pave the way for new construction for better economic growth. RA actually results from the crushing of concrete waste and this material, replacing natural aggregates, can be used in many applications such as: construction of low-rise buildings, manufacture of paving stones and tiles, laying of floor coverings and approach routes, in sewer structures and coarse sub-base of the roadway, in addition to the drainage layer in highways and retaining walls. The waste directly in the through the area can increases the problems in the environmental aspect. So the study of waste is necessary to be used as a partial replacement. The waste materials put forwards as new material development or can be used as additional natural source to protect environment from waste deposits. This industrial waste is dumped in near by area or lands and it is directly impact to reduce the fertility of the soil. The project includes the use of natural coarse aggregates which can be partially replaced by recycled concrete aggregates. In the work in 06 batches of different proportions of binders were prepared and cubes and beams were poured

\section{MATERIAL DESCRIPTIONS}

Civil Engineering concrete materials consist of basically cement, sand, aggregate \& water. Other than these the one of predominant waste materials is used in this project i.e. Recycled Aggregate(RA) Which is obtained from the old dismantled civil engineering work when the waste is treated as unuseful. The RA product is partials replaced with natural aggregate so that course position will be treated as same.

As per the below fig 1 shows the basic materials is added with recycled materials in to it. The RA is obtained from the Different dismantle concrete materials from different construction work sites such as rigid pavement site, building sites, testing labs. in the city of Indore. The both materials are 


\section{International Journal of Engineering Applied Sciences and Technology, 2020 \\ Vol. 4, Issue 12, ISSN No. 2455-2143, Pages 159-162 \\ Published Online April 2020 in IJEAST (http://www.ijeast.com)}

used as combined mix with each mix. Before use the basic fundamental test can be done i.e. initial(IST) and final(FST) setting time of cement, amount of silt content in sand and test of aggregate. Finally mixing is carried with to get the concrete mix.

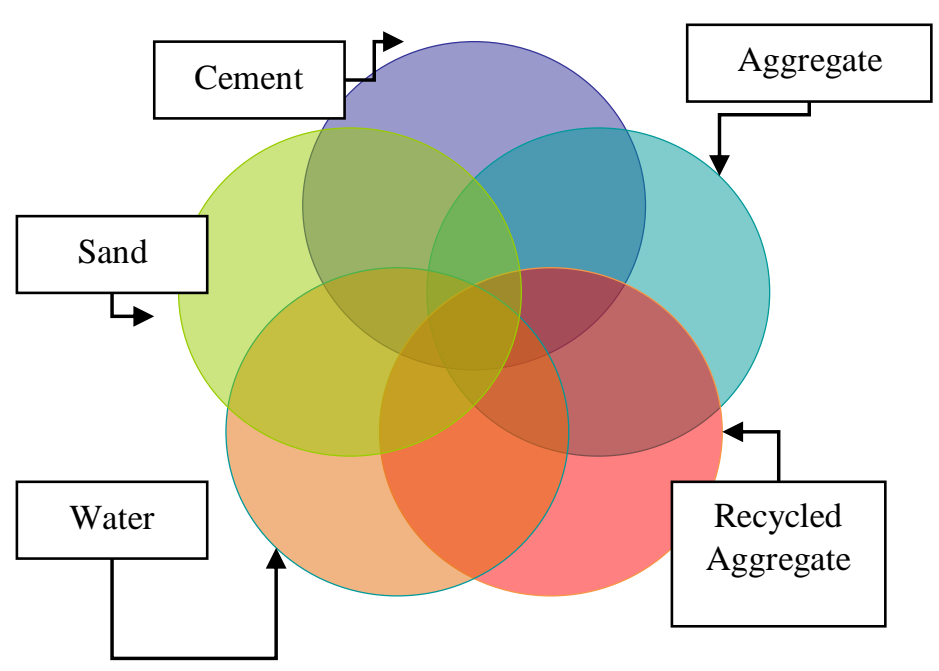

Fig 1 : Concrete Mix Materials

The result of testing of materials is as follows:

$\square$ Cement: For cement the basic test of consistency with initial and final setting time evolution the results get is $0.58 \mathrm{hr}$ (nearly by $0.5 \mathrm{hr}$ as specify in codes) and $9.75 \mathrm{hr}$ (nearly by $10 \mathrm{hr}$ as specify in codes) of OPC cement.

$\square$ Sand: The fundamental of silt contents in sand which is obtained as $7.3 \%$ (less than $10 \%$ as specify in codes)

$\square$ Aggregates: The value obtained are impact, Flakiness Index and elongation Index are 15.15, 37.83 and 30.86 respectively.

$\square$ Recycled Aggregate: The broken piece of recycled concrete is converted to $20 \mathrm{~mm}$ by $20 \mathrm{~mm}$ sieve size.

\section{FORMULATION APPROCH OF MIX}

In this stage of work natural aggregate (NA) is partially replaced by recycle aggregate (RA) in different percentages as shown in the table 1. batches are prepared in different proportions including conventional concrete mix (Cement as binder, Sand as fine aggregates, Natural Coarse Aggregates \& recycle coarse aggregate). Cubes and beams are casted for determining compressive and flexural strengths(FS) respectively at 7-14-28 days.
Table 1 Formulation of mix

\begin{tabular}{|r|r|r|r|r|}
\hline $\begin{array}{l}\text { Batch } \\
\text { Mix }\end{array}$ & \multicolumn{1}{|l|}{$\begin{array}{l}\text { Cement } \\
(\%)\end{array}$} & Sand (\%) & NA (\%) & RA(\%) \\
\hline 1 & 100 & 100 & 100 & - \\
\hline 2 & 100 & 100 & 95 & 05 \\
\hline 3 & 100 & 100 & 90 & 10 \\
\hline 4 & 100 & 100 & 85 & 15 \\
\hline 5 & 100 & 100 & 80 & 20 \\
\hline 6 & 100 & 100 & 75 & 25 \\
\hline
\end{tabular}

\section{RESULTS AND DISCUSSIONS}

In this the compressive strength(CS) and Flexural Strength(FS) test is perform of batch mix 01 to mix 06 by casted cubes and beams.

a) Compressive Strength:

Batching of each mix the group of 3 cubes for single day testing is constructed and evolution of compressive strength. Tests are performed at the interval of 7, 14, 28 days of the cube specimens. Placed of cubes in the test machine as per IS: 516-1959 clause no 5.5.1 page no 11, also loading is applied on the specimen as per the same IS code. As there are three specimens for each batch mix, the average of the three values is taken.

Table 2 Compressive Strength Result

\begin{tabular}{|c|c|c|c|c|}
\hline \multirow[b]{2}{*}{ S.N. } & \multirow[b]{2}{*}{$\begin{array}{c}\text { Combinati } \\
\text { on }\end{array}$} & \multicolumn{3}{|c|}{ Compressive Strength $\left(\mathrm{N} / \mathrm{mm}^{2}\right)$} \\
\hline & & 7 ays & $\begin{array}{c}14 \\
\text { Days }\end{array}$ & $\begin{array}{c}28 \\
\text { days }\end{array}$ \\
\hline $\begin{array}{c}\text { Mix- } \\
01\end{array}$ & $\mathrm{C}+\mathrm{S}+\mathrm{NA}$ & $\begin{array}{c}18.1 \\
7\end{array}$ & 20.63 & 24.13 \\
\hline $\begin{array}{c}\text { Mix- } \\
02\end{array}$ & $\begin{array}{c}\mathrm{C}+\mathrm{S}+90 \% \\
\mathrm{NA}+ \\
5 \% \mathrm{RA}\end{array}$ & $\begin{array}{c}23.2 \\
0\end{array}$ & 26.40 & 30.61 \\
\hline $\begin{array}{c}\text { Mix- } \\
03\end{array}$ & $\begin{array}{c}\mathrm{C}+\mathrm{S}+85 \% \\
\mathrm{NA}+ \\
10 \% \mathrm{RA}\end{array}$ & $\begin{array}{c}23.4 \\
9\end{array}$ & 27.36 & 31.02 \\
\hline $\begin{array}{c}\text { Mix- } \\
04\end{array}$ & $\begin{array}{c}\mathrm{C}+\mathrm{S}+80 \% \\
\mathrm{NA}+ \\
15 \% \mathrm{RA}\end{array}$ & $\begin{array}{c}20.5 \\
8\end{array}$ & 24.51 & 27.36 \\
\hline $\begin{array}{c}\text { Mix- } \\
05\end{array}$ & $\begin{array}{c}\mathrm{C}+\mathrm{S}+75 \% \\
\mathrm{NA}+ \\
20 \% \mathrm{RA}\end{array}$ & 19.91 & 23.02 & 26.52 \\
\hline $\begin{array}{c}\text { Mix- } \\
06\end{array}$ & $\begin{array}{c}\mathrm{C}+\mathrm{S}+90 \% \\
\mathrm{NA}+ \\
25 \% \mathrm{RA}\end{array}$ & 19.68 & 22.74 & 26.24 \\
\hline
\end{tabular}




\section{International Journal of Engineering Applied Sciences and Technology, 2020 \\ Vol. 4, Issue 12, ISSN No. 2455-2143, Pages 159-162 \\ Published Online April 2020 in IJEAST (http://www.ijeast.com)}

\section{b) Flexural Strength:-}

To determine the flex. (Tensile) Strength of Beams of size $100 \mathrm{~mm} \times 100 \mathrm{~mm} \times 500 \mathrm{~mm}$ are casted. Testing of beam can be evaluated in the interval of $7,14 \& 28$ days of the rectangular beam specimen. Placement for testing is taken with respect to IS: 516- 1959 mentioned in clause no 8.3.1 page no 17. Loading is taken as per at increasing rate of $1.8 \mathrm{KN} / \mathrm{min}$. recorded load is noted specimen fails. Calculated flexural strength result is tabulated below:-

Table 3: Flexural Strength Result

\begin{tabular}{|c|c|c|c|c|}
\hline \multirow{2}{*}{ S.N. } & \multirow{2}{*}{ Combination } & \multicolumn{3}{|c|}{ Tensile Strength $\left(\mathrm{N} / \mathrm{mm}^{2}\right)$} \\
\hline & & 7 Days & 14 Days & 28 days \\
\hline $\begin{array}{c}\text { Mix- } \\
01\end{array}$ & $\mathrm{C}+\mathrm{S}+\mathrm{NA}$ & 3.88 & 4.45 & 5.14 \\
\hline $\begin{array}{c}\text { Mix- } \\
02\end{array}$ & $\begin{array}{c}\mathrm{C}+\mathrm{S}+90 \% \mathrm{NA} \\
+ \\
5 \% \mathrm{RA}\end{array}$ & 4.85 & 5.58 & 6.43 \\
\hline $\begin{array}{c}\text { Mix- } \\
03\end{array}$ & $\begin{array}{c}\mathrm{C}+\mathrm{S}+85 \% \mathrm{NA} \\
+ \\
10 \% \mathrm{RA}\end{array}$ & 5.17 & 6.03 & 6.93 \\
\hline $\begin{array}{c}\text { Mix- } \\
04\end{array}$ & $\begin{array}{c}\mathrm{C}+\mathrm{S}+80 \% \mathrm{NA} \\
+ \\
15 \% \mathrm{RA}\end{array}$ & 4.22 & 4.92 & 5.65 \\
\hline $\begin{array}{c}\text { Mix- } \\
05\end{array}$ & $\begin{array}{c}\mathrm{C}+\mathrm{S}+75 \% \mathrm{NA} \\
+ \\
20 \% \mathrm{RA}\end{array}$ & 4.18 & 4.83 & 5.57 \\
\hline $\begin{array}{c}\text { Mix- } \\
06\end{array}$ & $\begin{array}{c}\mathrm{C}+\mathrm{S}+90 \% \mathrm{NA} \\
+ \\
25 \% \mathrm{RA}\end{array}$ & 4.12 & 4.74 & 5.32 \\
\hline
\end{tabular}

Partial replacement of NCA by RCA

a) Compressive strength:-

The figure 01 is showing compressive strength(CS) of Specimens of cubes at 7, $14 \& 28$ days of curing. When analyzed, strength of Mix-01 to Mix 06 with replacement 5\%, $10 \%, 15 \%, 20 \%$ \& $25 \%$ are shown approximately $29 \%$ of strength increased when compared with conventional mix, which is more $(2 \%)$ than optimum results of stage 1 . Also, on further increment of RCA, strength decrement was observed.

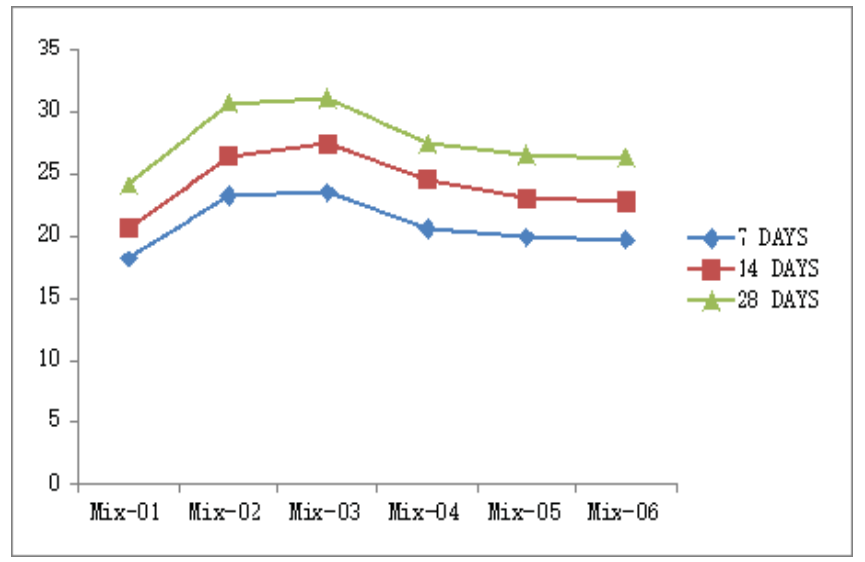

Fig1 : Curve for compressive strength. a) Flexural Strength:-

. The strength obtained from Mix 01 to Mix 06 is shown in the figure 02 having different percentage of replacement $5 \%$, $10 \%, 15 \%, 20 \%$ \& 25\%. When mix proportion giving optimum strengths The graph shown in figure 02 is plotted which shows, there is an improved flexura strength is obtained. For mix-03 when 10\% NCA was replaced by RCA, optimum strength was achieved.

Fig 2: Curve for Flexural Strength

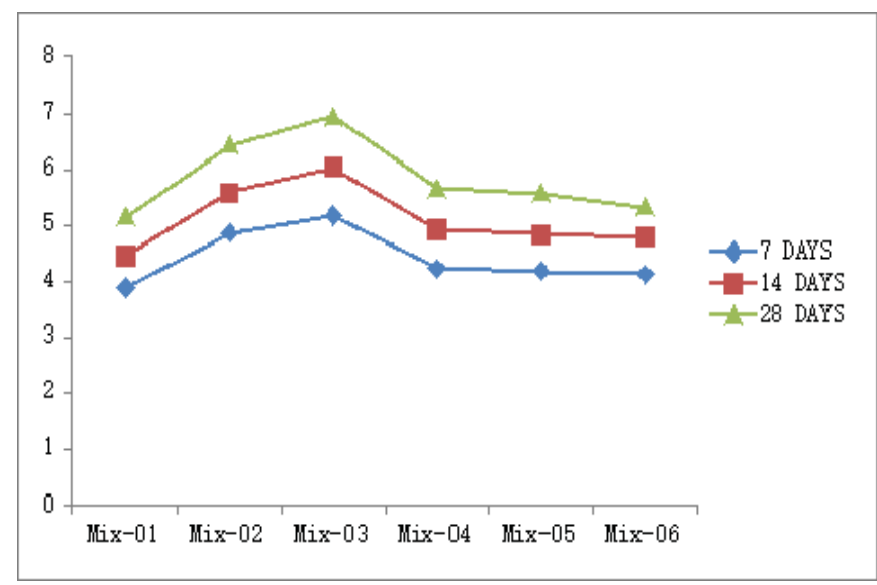

V. CONCLUSION

Based on the result and discussion obtained in the project, this research work can be concluded as the following point and all point are valid only for this project only.

- When $10 \%$ NA was replaced by RA an approximately $29 \%$ of strength increased when compared with conventional mix, which is more $(2 \%)$ than optimum results of stage 1 . Also, on further increment of RA, strength decrement was observed.

- When mix proportion giving optimum strengths The graph shown in figure 02 is plotted which shows, there is an improved flexural strength is obtained. For mix-03 when $10 \%$ NA was replaced by RA, optimum strength was achieved. It was even more than maximum strength.

- The NA is replaced by RA in it by $10 \%$ NA replacement by RA gives a higher strength values for both compressive and flexural.

- Increment in RA by replacing with NA, there is a decrement in strength is observed. But in case of $10 \%$ replacement of NA by RA gives increment in strength. 


\section{International Journal of Engineering Applied Sciences and Technology, 2020 \\ Vol. 4, Issue 12, ISSN No. 2455-2143, Pages 159-162 \\ Published Online April 2020 in IJEAST (http://www.ijeast.com)}

- Peak value of compressive and flexural strength is obtained under the $10 \%$ NA are replaced by RA for all 7- 14-28 time in days intervals.

- Increment in flexural strength(FS) is more with respect to compressive strength(CS) with Partial replaced with RA.

\section{REFERENCE}

[1] UmapathY \& Siva K et. al. "Assessment of Concrete Strength Using PartialReplacement of Coarrse Aggregte for waste Tiles and Cement for Rice Husk Ash in Concrete, IJERA ISSN : 2248-9622, Vol. 4, Issue 5( Version 1), May 2014, pp.72-76(2014)

[2] Reddy \& Shaik et.al. "Experimental analysis of the use of coconut shell as coarse aggregate", IOSR-JMCE) e-ISSN: 2278-1684,p-ISSN: 2320-334X, Volume 10, Issue 6 (Jan. 2014), PP 06-13(2014)

[3] A. Rathod \& Pitroda "A Study on Recycled Aggregate as a Substitute to Natural Aggregate for Sustainable Development in India”.(2013)

[4] Petkovic, Mehus, et.al. "Recycled concrete aggregate for durability aspects" (2005)

[5] Vinit Kumar, Vikas Srivastava \& et. al. "Effect of Fly Ash as Partial Replacement of Cement in PPC Concrete" International Journal of Innovative Research in Science, Engineering and Technology(An ISO 3297: 2007 Certified Organization)Vol. 4, Issue 7 (2015)

[6] Nordin, Mustafa \& et.al. 'Utilization Of Fly Ash Wastes Construction Material' International Journal of conservation Science Volume 7, Issue 1,: ISSN: 2067533X, 161-166 (2016)

[7] Lodhi ,Akhtar \& et.al. "Application of Paper Waste in Cement Concrete' Int. Journal of Engineering Research and Applications www.ijera.comISSN : 2248-9622, Vol. 5, Issue 4, ( Part -7) pp.95-98(2015)

[8] Indian Standard code of practice IS: 456-2000, "Plain And Reinforced Concrete-Code Of Practice". (2000)

[9] Indian Standard code of practice IS: 10262-2009, "Recommended Guidelines for Concrete Mix Design". (2009)

[10] Manual for Highway Engineering . By Khanna and Justo. (2010)

[11] P.A. Shirule, \& Ataur Rahman, et. al. "Partial Replacement of Cement with Marble Dust Powder" (2012)

[12] Vijayakumar, \& Vishaliny \& et. al. "Glass Powder As Partial Replacement of Cement in Concrete Production" ( 2013)

[13] A.Raghu Teja and B.K.Chaitanya "Partial Cement Replaceable By Agriculture Waste Published" (2007)
[14] Biruk Hailu and Abebe Dinku "Application of Sugarcane Bagasse as a Partial Cement Replacement" (2012).

[15] S.L. Patil , S.H. Kale, S. Suman "Partial Replacement of Cement with Fly ash" (2012)

[16] Concrete technology by MS shetty.(2012)

[17] Joseph \& Mary Review \& et. al. Paper On Partial Replacement Of Cement With Waste Material International Journal For Research In Emerging Science And Technology, Volume -3, Issue-12, DEC-2016EISSN: 2349-7610 